\title{
Purification and properties of a thermostable fumarate hydratase from the archaeobacterium Sulfolobus solfataricus
}

\author{
Susanne Puchegger, Bernhard Redi* and Georg StöFfler \\ Institut für Mikrobiologie (Medizinische Fakultät), Universität Innsbruck, Fritz Pregl Str. 3, A-6020 Innsbruck, Austria
}

(Received 18 April 1990; accepted 16 May 1990)

\begin{abstract}
Fumarate hydratase (EC 4.2.1.2) from the extremely thermophilic archaeobacterium Solfolobus solfataricus has been purified to homogeneity by a rapid purification procedure using affinity chromatography and highperformance size-exclusion chromatography, and the enzyme's physical and biochemical properties have been determined. The native enzyme has a molecular mass of $170 \mathrm{kDa}$ and is composed of identical subunits with a molecular mass of $45 \mathrm{kDa}$, thus indicating a tetrameric structure similar to fumarases isolated from other organisms. The enzyme was active at temperatures ranging from $40^{\circ} \mathrm{C}$ to $90^{\circ} \mathrm{C}$, with a maximum activity at $85^{\circ} \mathrm{C}$. The pH optimum for generation of fumarate was found to be pH 8.0. The enzyme showed high stability to denaturation by heat and organic solvents.
\end{abstract}

\section{Introduction}

Fumarate hydratase, or fumarase (EC 4.2.1.2), which catalyses the reversible hydration of fumaric acid to Lmalate, is an integral part of the tricarboxylic acid (TCA) cycle. It is widely distributed in plants, animals and bacteria. Most studies have been concerned with mammalian fumarases, which function in the mitochondrial TCA cycle and in cytosolic metabolism (Kanarek et al., 1964; Kobayashi et al., 1981; Kobayashi \& Tuboi, 1983; Sacchettini et al., 1986; Beeckmans \& Kanarek, 1982).

Fumarases from micro-organisms have been studied less extensively. In Escherichia coli it was found that there were two biochemically distinct classes of fumarases, which may function not only in the TCA cycle, during aerobic metabolism, but also, under anaerobic conditions, in the ultimate reduction of malate by providing fumarate as an anaerobic electron acceptor (Woods et al., 1988). One of these fumarases (class II) exhibits remarkable sequence homologies and biochemical properties with fumarases of Bacillus subtilis, Saccharomyces cerevisiae and human liver (Woods et al., 1986; Wu \& Tzagoloff, 1987).

Since archaeobacteria represent a third line of evolution, alongside eubacteria and eukaryotes (Woese \& Fox, 1977), the study of enzymes from these organisms may increase our understanding of protein evolution.

Abbreviation: TCA, tricarboxylic acid.
Furthermore, some enzymes from extremely thermophilic archaeobacteria have not only a high thermostability, but also a high chemostability (Buonocore et al., 1980; Giardina et al., 1986) and may therefore have biotechnological applications.

In this paper, we describe the purification and characterization of the thermostable fumarase of Sulfolobus solfataricus, an extremely thermophilic sulphurdependent archaeobacterium, which was isolated from hot acid habitats.

\section{Methods}

Organism and culture conditions. S. solfataricus, strain DSM 1616, was originally isolated from a volcanic hot spring (Brock et al., 1972). Cells were grown at $85^{\circ} \mathrm{C}$ in a 41 glass fermenter with low agitation, and aeration flux of $30 \mathrm{ml} \mathrm{min}^{-1}(1 \text { of broth })^{-1}$. The culture medium contained: $3.1 \mathrm{~g} \mathrm{KH}_{2} \mathrm{PO}_{4}, 2.5 \mathrm{~g}\left(\mathrm{NH}_{4}\right)_{2} \mathrm{SO}_{4}, 0.2 \mathrm{~g} \mathrm{MgSO}_{4} .7 \mathrm{H}_{2} \mathrm{O}$, $0.25 \mathrm{~g} \mathrm{CaCl}_{2} .2 \mathrm{H}_{2} \mathrm{O}, 2.0 \mathrm{~g}$ yeast extract in 11 of distilled water. The $\mathrm{pH}$ of the medium was adjusted to 3.5 with $10 \mathrm{M}-\mathrm{H}_{2} \mathrm{SO}_{4}$. Cell growth was monitored by following the optical density at $540 \mathrm{~nm}$. At an $\mathrm{OD}_{540}$ of 0.6 the $\mathrm{pH}$ of the medium was adjusted to 6.0 by adding $5 \mathrm{M}-\mathrm{NaOH}$ dropwise. Cells were then put on ice and harvested by centrifugation $(15 \mathrm{~min}$ at $10000 \mathrm{~g})$

Enzyme assay. Fumarase was routinely assayed at $70^{\circ} \mathrm{C}$ in $100 \mathrm{~mm}$ potassium phosphate buffer ( $\mathrm{pH} 7.5$ ) containing $50 \mathrm{mM}-\mathrm{L}$-malate, by monitoring the production of fumarate as a change in absorbance at $240 \mathrm{~nm}$. The measurements were made over a period of $10 \mathrm{~min}$ in a Beckman spectrophotometer equipped with a thermostatically controlled autosampler. One unit of enzyme activity (U) is defined as the amount of enzyme catalysing the formation of $1 \mu \mathrm{mol}$ of fumarate per 
min, using an extinction coefficient for fumarate of $2.44 \mathrm{mM}^{-1} \mathrm{~cm}^{-1}$ at $240 \mathrm{~nm}$.

Purification of fumarase. All purification steps were carried out at $4{ }^{\circ} \mathrm{C}$.

(i) Crude extract. Wet-frozen cells $(7 \mathrm{~g})$ were thawed in $14 \mathrm{ml}$ of buffer $\mathrm{A}(50 \mathrm{mM}-\mathrm{Tris} / \mathrm{HCl}$ buffer, $\mathrm{pH} \mathrm{7.5)}$ and disrupted by passing them twice through a French pressure cell operated at a pressure of $97 \mathrm{MPa}$. The suspension was centrifuged at $40000 \mathrm{~g}$ for $45 \mathrm{~min}$ at $4{ }^{\circ} \mathrm{C}$.

(ii) Precipitation with protamine sulphate. Nucleic acids were precipitated by adding $0.2 \mathrm{ml} 2 \%(\mathrm{w} / \mathrm{v})$ protamine sulphate in buffer $A$ per ml of crude extract. After $60 \mathrm{~min}$ at $4{ }^{\circ} \mathrm{C}$, with slow stirring, the precipitated material was removed by centrifugation at $40000 \mathrm{~g}$ for $30 \mathrm{~min}$ at $4{ }^{\circ} \mathrm{C}$. The supernatant was dialysed against several changes of buffer B (20 mM-Tris/ $\mathrm{HCl}$ buffer $\mathrm{pH} 6.8,5 \mathrm{~mm}-\mathrm{MgCl}_{2}, 0 \cdot 4 \mathrm{~mm}$-EDTA) overnight.

(iii) Dye affinity chromatography on Affi-Gel Blue gel. NAD, NADH, NADP and NADPH were added to the protein solution, to a final concentration of $0.5 \mathrm{mM}$ with respect to each pyridine nucleotide. This solution was applied to an Affi-Gel Blue (Bio-Rad) column $(16 \times 60 \mathrm{~mm})$ previously equilibrated with buffer $B$. The column was washed with 2 vols $(20 \mathrm{ml})$ of buffer B containing $0.1 \mathrm{mM}$ of each pyridine nucleotide. Affinity elution was performed with a linear gradient $(30 \mathrm{ml})$ from 0 to $10 \mathrm{~mm}$ fumarate in buffer $\mathbf{B}$ at a flow rate of $40 \mathrm{ml} \mathrm{h}^{-1}$. Fractions containing fumarase activity were pooled and concentrated.

(iv) High-performance size-exclusion chromatography. The concentrated protein solution was applied to a Bio-Sil (Bio-Rad) TSK 250 column $(600 \times 7.5 \mathrm{~mm})$ and eluted with $20 \mathrm{~mm}$-phosphate-buffered saline ( $20 \mathrm{~mm}$-sodium phosphate, $0.15 \mathrm{M}-\mathrm{NaCl}, \mathrm{pH} 7 \cdot 0$ ), at a flow rate of $1 \mathrm{ml} \mathrm{min}-1$. Fractions showing fumarase activity were pooled and stored at $-80^{\circ} \mathrm{C}$.

Electrophoresis and isoelectric focusing. SDS-polyacrylamide gel electrophoresis (SDS-PAGE) was used to check protein purity, and to determine the molecular mass of the purified enzyme under denaturing conditions. Protein samples were boiled for $5 \mathrm{~min}$ in $10 \mathrm{~mm}$-sodium phosphate, pH 7.0, $2 \%$ (w/v) SDS and $1 \%$ (v/v) 2-mercaptoethanol, prior to electrophoresis on $10 \%(\mathrm{w} / \mathrm{v})$ polyacrylamide slab gels using a Mini-Protean electrophoresis unit (Bio-Rad). After electrophoresis, protein bands were visualized by a silver staining procedure (Merill et al., 1981). The subunit molecular mass was determined using the Sigma MW-SDS-200 calibration kit.

The isolelectric point $(\mathrm{pI})$ of the fumarase was determined with an LKB Multiphor apparatus using broad-range $\mathrm{pH}$ (3.5-9.5) thin-layer polyacrylamide gels (Görg et al., 1978). Appropriate Pharmacia calibration kits were used. The proteins were stained with Coomassie Brilliant Blue $\mathrm{R}$ and densitometer scans were used to assess the pI.

Molecular mass estimation of native enzyme. The purified fumarase was chromatographed on a Bio-Gel (BioRad) A 1.5 gel filtration column $(8 \times 800 \mathrm{~mm})$, calibrated with ferritin $(450 \mathrm{kDa})$, aldolase $(160 \mathrm{kDa})$, bovine albumin $(67 \mathrm{kDa})$ and chymotrypsinogen $\mathrm{A}$ $(25 \mathrm{kDa})$. The eluting buffer was buffer $B$ with $\mathrm{NaCl}$ added to $100 \mathrm{~mm}$; fractions of $1 \mathrm{ml}$ were collected at a flow rate of $1.9 \mathrm{ml} \mathrm{h}^{-1}$. A computing integrator was used for monitoring peak area and retention time. The molecular mass of the purified native enzyme was also estimated by sucrose-density-gradient centrifugation as described by Martin \& Ames (1961). An enzyme sample (30 $\mu \mathrm{g}$ in $0.2 \mathrm{ml})$ was layered onto a preformed $10-30 \%$ sucrose gradient. Catalase $(240 \mathrm{kDa})$, albumin $(67 \mathrm{kDa})$ and horse myoglobin $(17 \mathrm{kDa})$ were used as markers. Centrifugation was carried out at $4{ }^{\circ} \mathrm{C}$ and 28500 r.p.m. for $15 \mathrm{~h}$ in a Beckman SW41 rotor.

pH and temperature relationships. The enzyme activity as a function of $\mathrm{pH}$ was tested using $50 \mathrm{~mm}$-potassium phosphate for $\mathrm{pH}$ values 5-5-7.5 and $50 \mathrm{mM}$ Tris $/ \mathrm{HCl}$ for $\mathrm{pH}$ values $7 \cdot 0-9 \cdot 0$ by the assay described above. $\mathrm{NaCl}$ was added to each buffer to bring the ionic strength to the same value. All pH values were adjusted at the appropriate temperature. The relationship between fumarase activity and temperature was determined at between $30^{\circ} \mathrm{C}$ and $95^{\circ} \mathrm{C}$, using the standard assay.

Kinetics. The kinetic parameters of S. solfataricus fumarase for Lmalate and fumarate were determined at $70^{\circ} \mathrm{C}$, using the activity assay described above, but $50 \mathrm{~mm}$-Tris/acetate, $\mathrm{pH} 7 \cdot 0$, was used as buffer instead of potassium phosphate. Fumarate was used as substrate instead of L-malate for determination of $K_{\mathrm{m}}$ for fumarate. The disappearance of fumarate was monitored as a decrease in absorbance at $240 \mathrm{~nm}$. The $K_{\mathrm{m}}$ values were estimated by the double reciprocal plot method.

\section{Results and Discussion}

\section{Enzyme purification}

A rapid two-step procedure using affinity chromatography and high-performance size-exclusion chromatography was used to purify fumarase from $S$. solfataricus.

The crude extract was loaded onto an Affi-Gel Blue column in a buffer containing all four pyridine nucleotides to prevent the binding of pyridine-nucleotidebinding enzymes to the column. When all unbound proteins had passed through the column, fumarase was specifically eluted with a linear gradient of $0-10 \mathrm{mM}-$ fumarate in the absence of pyridine nucleotides. For some preparations, proteins were fractionated by ammonium sulphate (55-70\% saturation) prior to loading onto the column. After elution with fumarate, the protein fraction appeared to be almost homogeneous; however, using this purification scheme, the overall yield was significantly lower. In each case an additional $3-5 \%$ of the bound fumarase activity was eluted with $0.5 \mathrm{M}-\mathrm{NaCl}$; however, this fraction contained a large amount of contaminating proteins. For final purification, fractions showing fumarase activity were pooled and applied to a size-exclusion HPLC column as described in Methods. The progress of purification was monitored by SDSPAGE (Fig. 1), and a typical purification is summarized in Table 1. From this it is evident that the most effective purification step was the dye-affinity chromatography.

\section{Molecular mass and isoelectric point}

The purified enzyme was detected as a single band with a molecular mass of $45 \mathrm{kDa}$ using SDS-PAGE (Fig. 1, Lane 3).

The molecular mass of the native enzyme was estimated by gel filtration chromatography and by sucrose gradient centrifugation. The values obtained were $170 \mathrm{kDa}$ and $160 \mathrm{kDa}$ respectively, suggesting that the native protein is composed of four identical subunits.

With respect to the subunit molecular mass and the 
Table 1. Purification of fumarase from $S$. solfataricus

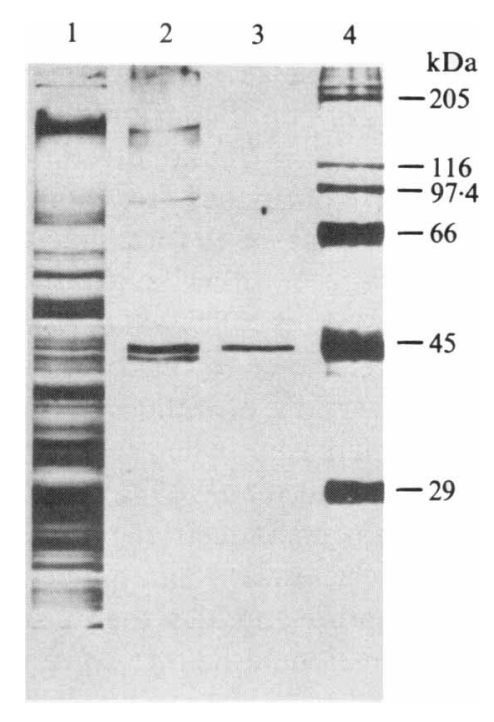

Fig. 1. Progress of fumarase purification monitored by SDS-PAGE. Samples from different purification steps were electrophoresed on $10 \%$ acrylamide slab gels, and proteins were visualized by silver staining. The lanes contained: $1,25 \mu \mathrm{g}$ of crude cell extract; $2,2.5 \mu \mathrm{g}$ of proteins eluted from Affi-Gel Blue gel with fumarate; 3, $1.5 \mu \mathrm{g}$ of purified fumarase; 4 , molecular mass markers.

tetrameric structure the $S$. solfataricus fumarase closely resembles fumarases purified from $B$. subtilis and pig heart and a fumarase from $E$. coli encoded by the gene fumC (Shibata et al., 1985; Kanarek et al., 1964; Woods et al., 1988). It is different from a fumarase from Euglena gracilis and two additional fumarases from $E$. coli (encoded by the genes fumA and fumB), which are dimeric proteins with subunit molecular masses of $60 \mathrm{kDa}$ (Shibata et al., 1985; Woods et al., 1988).

The pI of the fumarase was estimated to be $7 \cdot 1$ by isoelectric focusing.

\section{Substrate specificities and kinetic studies}

The substrate specificities of the enzyme were tested, using D-malate, maleate, citramalate and citrate (obtained from Sigma) instead of L-malate or fumarate, but no activity could be detected with these substrates. This clearly demonstrates that the enzyme is a fumarase, rather than a hydratase with a broad substrate specificity that includes fumarate.

Purified enzyme was used for determination of the kinetic properties and tests were performed in $50 \mathrm{~mm}$ Tris/acetate $(\mathrm{pH} 7.0)$. The rate of fumarate or malate

\begin{tabular}{|c|c|c|c|c|c|}
\hline \multirow[b]{2}{*}{ Step } & \multirow{2}{*}{$\begin{array}{l}\text { Total } \\
\text { protein } \\
(\mathrm{mg})\end{array}$} & \multirow{2}{*}{$\begin{array}{c}\text { Total } \\
\text { activity } \\
\text { (U) }\end{array}$} & \multirow{2}{*}{$\begin{array}{l}\text { Specific } \\
\text { activity } \\
\left(\mathrm{U} \mathrm{mg}^{-1}\right)\end{array}$} & \multicolumn{2}{|c|}{$\begin{array}{l}\text { Purification } \\
\text { yield }\end{array}$} \\
\hline & & & & (-fold) & $(\%)$ \\
\hline Cleared lysate & $237 \cdot 0$ & 192 & 0.81 & 1 & 100 \\
\hline Protamine sulphate & $214 \cdot 0$ & 179 & 0.84 & 1 & 93 \\
\hline Affi-Gel Blue & $1 \cdot 5$ & 65 & 43.33 & 53 & 34 \\
\hline Size-exclusion HPLC & $0 \cdot 2$ & 41 & $205 \cdot 00$ & 253 & 21 \\
\hline
\end{tabular}

formation was measured over a range of substrate concentrations of $0 \cdot 1-10 \mathrm{mM}-\mathrm{L}-\mathrm{malate}$ and $0.025-1 \mathrm{mM}$ fumarate respectively. The $K_{\mathrm{m}}$ for malate was $0.30 \mathrm{mM}$, which is comparable to that of E. gracilis (Shibata et al., 1985 ) and rat liver (Kobayashi et al., 1981). The $K_{\mathrm{m}}$ for fumarate was $0.125 \mathrm{mM}$, a $K_{\mathrm{m}}$ comparable to that of the E. coli fumarase encoded by the gene fumC (Woods et al., 1988) but higher than that for the mammalian enzymes. It is apparent that the $S$. solfataricus fumarase has a $2 \cdot 5-$ fold greater affinity for fumarate than for malate, which is consistent with the aerobic function of this enzyme in the TCA cycle.

Since it was reported that the kinetic constants of rat liver fumarase were affected by phosphate (Kobayashi $e t$ al., 1981), the effect of potassium phosphate on kinetic properties of the $S$. solfataricus enzyme was tested. Addition of $10 \mathrm{mM}-\mathrm{K}_{3} \mathrm{PO}_{4}$ to the test mixture resulted in an increase of $K_{\mathrm{m}}$ for malate and fumarate to $0.45 \mathrm{mM}$ and $0.27 \mathrm{mM}$ respectively. The inhibition of $S$. solfataricus fumarase by phosphate was less than that for rat liver fumarase, for which the addition of $10 \mathrm{mM}-\mathrm{K}_{3} \mathrm{PO}_{4}$ resulted in an increase of $K_{\mathrm{m}}$ from $0.013 \mathrm{mM}$ to $0.33 \mathrm{mM}$ for fumarate and $0.14 \mathrm{mM}$ to $0.60 \mathrm{mM}$ for malate (Kobayashi et al., 1981).

\section{Factors affecting enzyme activity and stability}

The enzyme activity versus $\mathrm{pH}$ was determined over the range $\mathrm{pH} 5 \cdot 0-9 \cdot 0$. In the range $\mathrm{pH} 6 \cdot 5-8 \cdot 5$, fumarase exhibited $90-100 \%$ activity, with a maximum at $\mathrm{pH} 8 \cdot 0$. At pH 5.5 the enzyme exhibited $43 \%$, and at pH $9.0,70 \%$ of its maximum activity.

When enzyme activity was assayed at temperatures ranging from $40^{\circ} \mathrm{C}$ to $95^{\circ} \mathrm{C}$, maximum yield of fumarate production was recorded at $85^{\circ} \mathrm{C}$, using the $10 \mathrm{~min}$ assay. This value for maximum catalytic activity correlates with the optimal growth temperature of $S$. solfataricus. At $95^{\circ} \mathrm{C}$ the enzyme activity was still $66 \%$ of maximum, whereas at $40^{\circ} \mathrm{C}$ the enzyme was almost inactive. In this respect the fumarase closely resembles other enzymes from extremely thermophilic archaeobacteria, since a number of these enzymes are inactive at temperatures below $40^{\circ} \mathrm{C}$. The effects of temperature on 


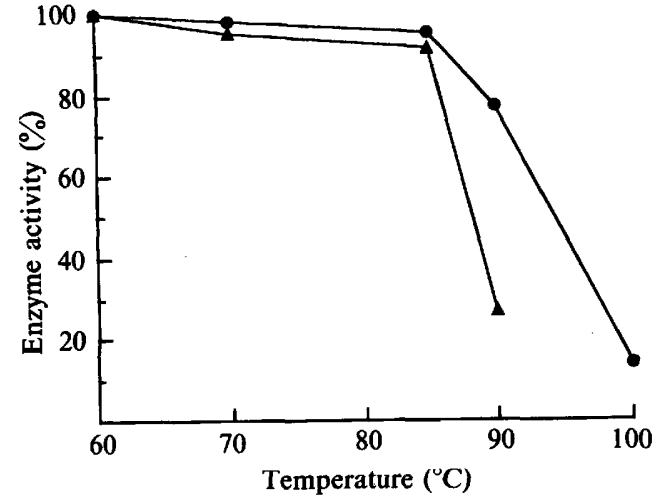

Fig. 2. Thermal inactivation of fumarase from $S$. solfataricus. $0 \cdot 3 \mu \mathrm{g}$ $(0.058 \mathrm{U})$ of enzyme was preincubated for $10 \mathrm{~min}(\boldsymbol{O})$ or $30 \mathrm{~min}(\boldsymbol{A})$ in $100 \mathrm{~mm}$-potassium phosphate buffer $\mathrm{pH} 7.5$ at the temperatures indicated. The remaining activity was determined using the standard assay.

Table 2. Effect of organic solvents and dissociating reagents on the activity of fumarase from $S$. solfataricus

\begin{tabular}{lcc}
\hline \hline \multirow{2}{*}{ Treatment } & \multicolumn{2}{c}{ Remaining activity $(\%)$} \\
\cline { 2 - 3 } & After $10 \mathrm{~h}$ at $20^{\circ} \mathrm{C}$ & After $14 \mathrm{~d}$ at $20^{\circ} \mathrm{C}$ \\
\hline None & 100 & 100 \\
Ethanol $(50 \%, \mathrm{v} / \mathrm{v})$ & 86 & 83 \\
Methanol $(50 \%, \mathrm{v} / \mathrm{v})$ & 102 & 104 \\
2-Propanol $(50 \%, \mathrm{v} / \mathrm{v})$ & 96 & 85 \\
4 M-Urea & 97 & 57 \\
$0 \cdot 1 \%$ SDS & 99 & 1 \\
\hline \hline
\end{tabular}

enzyme activity are reflected in the thermostability data presented in Fig. 2. The enzyme lost no activity when incubated at $70^{\circ} \mathrm{C}$ or $85^{\circ} \mathrm{C}$ for $1 \mathrm{~h}$ prior to assay. After preincubation at $90{ }^{\circ} \mathrm{C}$ for $30 \mathrm{~min}$ the enzyme activity. dropped to $28 \%$, and preincubation at $100^{\circ} \mathrm{C}$ for $30 \mathrm{~min}$ resulted in complete loss of activity.

The effect of organic solvents and dissociating reagents on enzyme activity was studied by preincubation of the purified enzyme in these reagents for $10 \mathrm{~h}$ or $14 \mathrm{~d}$ at room temperature (Table 2). After treatment with $50 \%(\mathrm{v} / \mathrm{v})$ ethanol, $50 \%(\mathrm{v} / \mathrm{v})$ methanol, $50 \%(\mathrm{v} / \mathrm{v}) 2-$ propanol, $4 \mathrm{M}$-urea or $0.1 \%$ SDS for $10 \mathrm{~h}$ at room temperature, no significant loss of enzyme activity was detected. Even preincubation for up to $14 \mathrm{~d}$ at room temperature in organic solvents resulted in only a slight loss of activity.

The relative activity of the enzyme was also determined in the organic solvents. The fumarase retained $94 \%$ of maximum activity in $40 \%(\mathrm{v} / \mathrm{v})$ methanol, but only $15-20 \%$ activity in $40 \%$ (v/v) 2-propanol and $40 \%$ (v/v) ethanol when the activity was assayed in these solvents.
As expected, the fumarase of $S$. solfataricus appeared to be more thermostable and more chemostable than the fumarases of other organisms studied to date. These properties could make this enzyme attractive for use in biotechnological processes, since fumarase activity is used industrially for continuous production of L-malate (Chibata et al., 1987; Yamamoto et al., 1977). The usefulness of a continuous reaction process using immobilized enzyme, as used for L-malate production, is largely determined by the enzyme's stability. The enhanced chemostability of $S$. solfataricus fumarase may therefore be of relevance to this process.

Enzymic conversion of fumarate to L-malate was shown to be increased when using magnesium or calcium fumarate (Ado et al., 1982); but these substrates cannot be used in an industrial process because their solubilities are very low at room temperature. The high optimum temperature and high thermostability of the $S$. solfataricus enzyme could help to solve these problems.

We are indebted to Dr P. V. Lemley for carefully reading the manuscript.

\section{References}

Ado, Y., Kawamoto, T., Masunaga, I., Takayama, K., Takasawa, S. \& KimURA, K. (1982). Production of L-malic acid with immobilized thermophilic bacterium, Thermus rubens nov. sp. Enzyme Engineering 6, 303-304.

Beeckmans, S. \& KanareK, L. (1982). Chicken heart fumarase: its purification and physico-chemical characterization. A comparison with the enzyme from pig heart. International Journal of Biochemistry $14,453-460$.

Brock, T. D., Brock, K. M., Belly, R. T. \& Weiss, R. L. (1972). Sulfolobus: a new genus of sulfur-oxidizing bacteria living at low $\mathrm{pH}$ and high temperature. Archives of Microbiology 84, 54-68.

Buonocore, V., Sgambati, O., De Rosa, M., Esposito, E. \& GAMBACORTA, A. (1980). A constitutive $\beta$-galactosidase from the extreme thermoacidophile archaebacterium Caldariella acidophila: properties of the enzyme in the free state and in immobilized whole cells. Journal of Applied Biochemistry 2, 390-397.

Chibata, I., Tosa, T. \& Sato, T. (1987). Application of immobilized biocatalysts in pharmaceutical and chemical industries. In Biotechnology, vol. 7a, pp. 653-684. Edited by H.-J. Rehm \& G. Reed. Weinheim: Verlag Chemie.

Giardina, P., De Biasi, M. G., De Rosa, M., Gambacorta, A. \& BUONOCORE, V. (1986). Glucose dehydrogenase from the thermoacidophilic archaeobacterium Sulfolobus solfataricus: Biochemical. Journal 239, 517-522.

GöRG, A., POSTEL, W. \& Westermeier, R. (1978). Ultrathin-layer isoelectric focusing in polyacrylamide gels on cellophane. Analytical Biochemistry 86, 60-70.

Kanarex, L., Marler, E., Bradshaw, R. A., Fellows, R. E. \& Hill, R. L. (1964). The subunits of fumarase. Journal of Biological Chemistry 239, 4207-4211.

KobaYASHI, K. \& TUBOI, S. (1983). End-group analysis of the cytosolic and mitochondrial fumarases from rat liver. Journal of Biochemistry 94, 707-713.

Kobayashi, K., Yamanishi, T. \& Tuboi, S. (1981). Physicochemical, catalytic, and immunochemical properties of fumarases crystallized separately from mitochondrial and cytosolic fractions of rat liver. Journal of Biochemistry 89, 1923-1931. 
Merill, C. R., Goldman, D., Sedman, S. A. \& Ebert, M. H. (1981). Ultrasensitive stain for proteins in polyacrylamide gels shows regional variation in cerebrospinal fluid proteins. Science 211, 14371438.

MarTin, R. G. \& AMEs, B. N. (1961). A method for determining the sedimentation behavior of enzymes: application to protein mixtures. Journal of Biological Chemistry 236, 1372-1379.

Sacchettini, J. C., Meininger, T., Roderick, S. \& Banaszak, L. J. (1986). Purification, crystallization, and preliminary X-ray data for porcine fumarase. Journal of Biological Chemistry 261, 1518315185.

Shibata, H., Gardiner, W. E. \& Schwartzbach, S. D. (1985). Purification, characterization, and immunological properties of fumarase from Euglena gracilis var. bacillaris. Journal of Bacteriology 164, 762-768

WOESE, C. R. \& Fox, G. E. (1977). Phylogenetic structure of the procaryotic domain: the primary kingdoms. Proceedings of the
National Academy of Sciences of the United States of America 74, 5088-5090.

Woods, S. A., Miles, J. S., Roberts, R. E. \& Guest, J. R. (1986). Structural and functional relationships between fumarase and aspartase. Nucleotide sequences of the fumarase ( $\mathrm{fumC}$ ) and aspartase (aspA) genes of Escherichia coli K12. Biochemical Journal 237, 547-557.

Woods, S. A., Schwartzbach, S. D. \& Guest, J. R. (1988). Two biochemically distinct classes of fumarase in Escherichia coli. Biochimica et Biophysica Acta 954, 14-26.

WU, M. \& TZAgolofF, A. (1987). Mitochondrial and cytoplasmic fumarases in Saccharomyces cerevisiae are encoded by a single nuclear gene fuml. Journal of Biological Chemistry 262, 12275-12282.

Yamamoto, K., Tosa, T., Yamashita, K. \& Chibata, I. (1977). Kinetics and decay of fumarase activity of immobilized Brevibacterium ammoniagenes cells for continuous production of L-malic acid. Biotechnology and Bioengineering 19, 1101-1114. 